\section{South African researchers want greater role in planning}

Cape Town. An initiative set up last May to look at how science should be run in South Africa in the period leading up to majority rule has come under fire from university scientists who claim that they are insufficiently represented in the discussions currently taking place.

The purpose of the initiative has been to discuss ways in which issues relating to the country's science system and future policy needs can be handled during the transition period and in a democratic South Africa.

But at a recent meeting of the Royal Society of South Africa, Dave Woods, deputy vice-chancellor for research at the University of Cape Town, expressed concern that the initiative was just a case of "the old bureaucrats and the new bureaucrats getting together". He pointed out that the members of the working group set up to develop the initiative contain only one practising scientist, Friedel Sellschop, his counterpart at the University of the Witwatersrand.

Woods' comments echo sentiments expressed previously by a meeting of black university scientists, headed by Chris Johson, dean of science at the University of the Western Cape. The meeting issued a statement calling for a moratorium on "all unilateral restructuring", and the urgent establishment of what it called a "national forum on science".

The 'Science and Technology Initiative', as it has become known, was originally intended to act as such a forum. It was launched in May in response to a critical report on the country's research system sponsored by the African National Congress (ANC), the Congress of South African Trade Unions (COSATU), and the South African National Civic Organization (SANCO), and carried out by Canada's International Development Research Centre (IDRC).

While two subsequent plenary sessions have been held, the driving force behind the initiative has been an eight-member working group. But university scientists are rep-

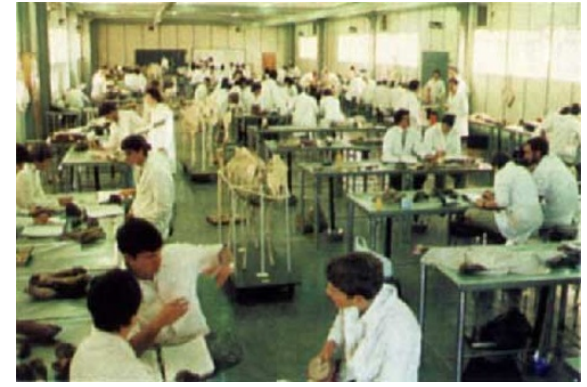

South Africa's universities will need to adapt to a new environment.

resented on the working group only through the Committee of University Principals, and feel that this is inadequate. In particular, in calling for a moratorium on unilateral restructuring, the black scientists claim that what they see as a non-representative body should not be responsible for implementing changes in South African science.

One priority identified by the working group is the need to devise a new system for funding science in the new federal South Africa. The discussion on this topic is being co-ordinated by Roger Jardine, co-ordinator of science and technology planning for the ANC. He favours adoption of a model similar to the German Wissenschaftsrat, under which funds are provided by central government but administered by a council made up of scientists and political representatives from each region of the country.

To the surprise of some observers, the working group has chosen not to intervene in the process of allocating the science budget for the 1994/5 financial year. This has angered the universities, who feel that they are getting a raw deal under the current funding proposals (see Nature 356, 9; 1992).

As before, the Scientific Advisory Board has not made public its recommendations to the cabinet, a stance which the IDRC review criticized as resulting in a situation where "no independent assessment can be made of the extent, quality, relevance or impact of its advice".

Michael Cherry

\section{Zoologist to head UK environment council}

London. The latest piece in the new jigsaw of British science was put into place this week with the announcement that John Krebs will become chief executive of the Natural Environment Research Council from April. Krebs joins the line-up of scientists and industrialists who will head the newly structured research councils.

Krebs, a research professor in the department of zoology at the University of Oxford since 1988, takes control of the new council at a time when its remit is being increased to include atmospher the UK government's favoured project, Earth observation.

Widely known for his research on decision-making and memory in animals, Krebs is currently director of the Agriculture and Food Research Council's Unit of Ecology and Behaviour, and chairs the council's Animals Research Committee.

\section{Seismologists say Los Angeles quake sets 'ominous pattern'}

Washington. This week's Los Angeles earthquake has reinforced seismologists' fears that California is on track for a seismic event far more potent than the one which registered 6.6 on the Richter scale at $4: 31$ a.m. on Monday morning.

As the death toll from the tremor mounted, leading seismologists were preparing to investigate how the event, epicentred in the San Fernando valley just over 30 kilometres north-west of central Los Angeles, would fit into two equally troubling patterns of seismic activity in the state of California.

One pattern, which has been observed worldwide, is a tendency for major shocks of this type to happen once a decade or so in the run-up to a catastrophic earthquake. Monday's event follows a shock of the same strength in the San Fernando valley in 1971.

Allan Lindh of the United States Geological Survey's Menlo Park research centre near San Francisco says that such a pattern preceded the great San Francisco earthquake of 1906, and has also been noted in Russia and Japan. Lindh believes the event to be "extremely ominous".

The second, more localized pattern is one of increasingly regular, low level tremors in southern California. Monday's event is the fifth to register more than five on the Richter scale in the area just north of Los Angeles since 1987, says Lucy Jones of the US Geological Survey's station at the California Institute of Technology at Pasadena.

Like previous tremors, it took place on one of a set of buried faults in the Earth's crust, where stress builds up due to the proximity of an S-bend on the San Andreas fault, which passes some 50 kilometres away.

The scientific follow-through from the earthquake will also try to refine estimates of the frequency of such events, find out which faults are active, and investigate just how big such secondary events - short of the dreaded primary event on the San Andreas - could be in the future.

Chris Scholz from the Lamont-Doherty Earth Observatory of Columbia University, New York, says the event does confirm that stresses are building up in California which will at some stage be released by a major earthquake, of magnitude 8 or more on the San Andreas.

Such concerns led the National Science Foundation to set up a Southern California Earthquake Center three years ago, at the University of Southern California. But the centre has so far only received about half of its expected \$5 million-a-year funding: after Monday that, at least, may change.

Colin Macilwain 